\title{
A STUDY OF FUNCTIONAL OUTCOME OF TOTAL KNEE REPLACEMENT AT DISTRICT LEVEL HOSPITAL
}

\author{
Ankit Agur', Narasimharao Thutari' ${ }^{2}$ K. J. Reddy³, S. R. K. Dikshit ${ }^{4}$ \\ ${ }_{1}^{1}$ Assistant Professor, Department of Orthopaedics, Government Medical College, Mahabubnagar, Telangana, India. \\ ${ }^{2}$ Associate Professor, Department of Orthopaedics, Government Medical College, Mahabubnagar, Telangana, India. \\ 3 Professor and HOD, Department of Orthopaedics, SVS Medical College, Mahabubnagar, Telangana, India. \\ ${ }_{4}^{4}$ Assistant Professor, Department of Orthopaedics, SVS Medical College, Mahabubnagar, Telangana, India.
}

ABSTRACT

\section{BACKGROUND}

Arthritis of knee joint results in painful knee and causes disability in daily living. Medical management and physical therapy are useful in the management of patients with mild arthritis. Patients with severe arthritis can be treated successfully with total knee arthroplasty, where all other modalities of treatment are not successful.

\section{METHODS}

We studied 47 knees in 30 patients treated with total knee replacement using posteriorly stabilized implants at SVS Medical College Hospital from October 2012 to September 2014. Postoperatively, patients were assessed using knee society knee score.

\section{RESULTS}

In our study, mean knee score is 33.27 with standard deviation 7.77 preoperatively and 87.7 with standard deviation 5.96 postoperatively, showing significant improvement. Mean functional score is 36.67 with standard deviation 9.69, preoperatively and 78 with standard deviation 6.78 postoperatively.

\section{CONCLUSIONS}

Total Knee replacement is an effective and reliable method to treat patients with advanced arthritis of knee joint. It relieves pain and increases range of motion of the knee joint postoperatively and alleviates the disability of patient. Total Knee Replacement has evolved as a very effective surgical intervention after the conservative methods like NSAID's, Physiotherapy, Intra-articular steroid and Hyaluronic acid injections have failed. TKR is associated with numerous complications intra and post operatively and the surgeon should be aware of the complications and the need for the revision in a later stage. Pre op evaluation of the patient is of utmost importance in planning for the amount of correction to be achieved, component sizing, and requirement of wedge or bone grafts for bone loss. TKR even in young patients offers excellent results with early return to their daily activities. With the invention of newer equipment and instruments, TKR has been made easy and more accurate for the surgeon to retain normal kinematics of the knee.

\section{KEY WORDS}

Total Knee Replacement, Knee Joint, Arthritis, Arthroplasty

HOW TO CITE THIS ARTICLE: Agur A, Thutari N, Reddy KJ, et al. A study of functional outcome of total knee replacement at district level hospital. J. Evolution Med. Dent. Sci. 2019;8(26):2076-2080, DOI: 10.14260/jemds/2019/457

\section{BACKGROUND}

Knee is a complex synovial tri-compartmental joint. ${ }^{1}$ Arthritis of the knee joint causes severe disability with restriction of day to day activities and Total Knee Arthroplasty is now a reliable and well-established treatment for severe arthritis. ${ }^{2}$ Total Knee Arthroplasty is one of the most common orthopaedic procedures performed. More than 20 crore Indians are suffering from osteoarthritis. ${ }^{3}$ With increase in life expectancy and high demands of patients both young and elderly the number of patients undergoing TKR is increasing day by day. In the current medical scenario, total knee arthroplasty has been highly successful in alleviating the majority of patients suffering, disability and achieving comprehensive near normal functional freedom for the

'Financial or Other Competing Interest': None.

Submission 07-05-2019, Peer Review 13-06-2019,

Acceptance 20-06-2019, Published 01-07-2019.

Corresponding Author:

Dr. Narasimharao Thutari,

H. No. 7-5-106, Vandana Enclave,

Block-C, Flat-101, Venkateswara Colony,

Mahabubnagar-509001, Telangana, India.

E-mail: narasimharao.thutari@gmail.com

DOI: $10.14260 /$ jemds $/ 2019 / 457$ patients post-surgery when all other treatment modalities have failed. Several innovative improvisations in implant design and surgical techniques, most notable being computer navigation and Various systems are available with specific features regarding the geometry of the components, the degree of conformity of the articulating surfaces, and the anchoring technique which have helped in achieving the absolute normal kinematics and functions of the knee after TKR. The end result of arthritis is painful joint with severe deformity and TKR is the gold standard treatment for this condition. Since many studies are not available for assessing the outcome of TKR in our demography, I intend to take up "A Study of functional Outcome of Total Knee Arthroplasty at District Level Hospital".
Aim of The Study
Objectives of The Study
1. To assess pain relief post-operatively.
2. To assess stability and mobility of the joint.
3. To assess the correction of deformities.

To study the functional outcome of total knee arthroplasty using the Knee Society Score at SVS Medical College Hospital. 
4. To assess the complications associated with Total Knee Replacement.

\section{METHODS}

We did a prospective interventional study on the functional outcome of all the patients, satisfying inclusion and exclusion criteria, who underwent Total Knee Replacement using cemented posteriorly stabilized implants at SVS Medical College Hospital during the year October 2012 - September 2014.

\section{Data Collection}

From patients who underwent total knee arthroplasty-

- History by verbal communication.

- Clinical examination.

- $\quad$ Routine Blood investigations, HIV, HbS Ag.

- $\quad$ X ray knee joint - Anterior and Lateral views. Pre-op and post-operatively.

- Pre-operative and Post-operative data Evaluation- using Knee Society Knee Score. ${ }^{4}$

\section{Inclusion Criteria}

1. Patients with Primary osteoarthritis - Unilateral or bilateral.

2. Patients with Secondary osteoarthritis.

3. Patients with rheumatoid arthritis.

4. Patients willing to give consent.

\section{Exclusion Criteria}

1. Sepsis of knee joint.

2. Neuropathic joints.

3. Paralytic joints and neuro-muscular disorders.

4. Patients with local skin lesions.

\section{Surgical Procedure}

Surgery was performed under spinal with or without epidural anaesthesia. Patient positioned supine and the operating leg was positioned in flexion. A broad-spectrum antibiotic like ceftriaxone, sulbactam combination of $1.5 \mathrm{gm}$ IV and $100 \mathrm{mg}$ I.V. infusion of Tranexamic acid was given before tourniquet application. A thorough scrub was given. The part was painted with betadine solution. Sterile stockinette was used to drape the limb exposing only the operating area. Sterile drape was used for operative site.

A standard midline approach with knee in flexion was used from upper pole of patella till tibial tuberosity. Deeper anteromedial dissection was followed for arthrotomy. Medial, lateral, posterior soft tissue release either minimal or extensive was done for soft tissue balancing and correction of deformities. Tibial and femoral osteophytes were excised. Tibial sectioning was done using extramedullary cutting. We have sacrificed both the cruciates in all knees. Femoral section was done with appropriate femoral rotation with reference to epicondylar line or Whiteside line. Autologous posterior condylar grafts with screws or with wedge augmentation managed tibial defects. The alignment and soft tissue balance were checked in extension and flexion. Trial components were assembled for proper fit and checked for soft tissue tension and balancing in flexion and extension. Patellar tracking was noticed normal in all. Cementing of components was done by using one packet of bone cement. Tourniquet was released, haemostasis was achieved by cauterization. Drain was kept, wound was closed in layers. Antibiotics continued post operatively for 5 days. Standard postoperative protocol was followed to develop quadriceps strength, to improve the range of motion and early weight bearing ambulation. Sutures removed at the end of two weeks.

Immediate post-operative and follow-up clinical radiological evaluation was done at regular intervals. Final evaluation was done using KSS scoring system. All cases were photographically documented. The follow-up period was at 2 , $4,12,24$ weeks. Statistical analysis was done using chi square and $\mathrm{p}$ values wherever necessary and relevant tables and charts prepared.

\section{Post-Operative Protocol}

Day-1: Quadriceps strengthening exercises as permitted by the pain.

Day-2: Drain was removed if collection was less than $50 \mathrm{ml}$ on day 2 or on day 3.

Day-3: Active and passive assisted flexion as tolerated by the patient using continuous passive motion machine and less than $90^{\circ}$.

Day-5 to 7: Ambulation was encouraged using knee brace.

Day-9: Active exercises were encouraged including extension. By the time sutures were removed (12-14 days) patients were encouraged to have good muscle strength and knee control.

Statistical analysis was done using chi square and $\mathrm{p}$ values wherever necessary.

\section{RESULTS}

Most of the indications in our study belongs to Osteoarthritis (41 knees) and rheumatoid Arthritis (6 knees).

In our study 17 patients underwent bilateral Total Knee Replacement, 7 patients to right knees and 6 patients to left knees. Mean Age in our study is 61.6 yrs. In our study we included patients there were 6 cases from age group 51-55 yrs., 8 cases from 56-60 yrs., 7 cases from 61-65 yrs., 6 patients were $66-70$ and 3 patients were above 70 yrs.

In our study we had $80.0 \%$ of female patients and $20.0 \%$ male patients that is 26 female and 4 male patients.

In our study we had 17 patients without any associated conditions, 3 patients with Hypertension, 1 patient with obesity, 2 with DM and 7 patients with multiple comorbid conditions.

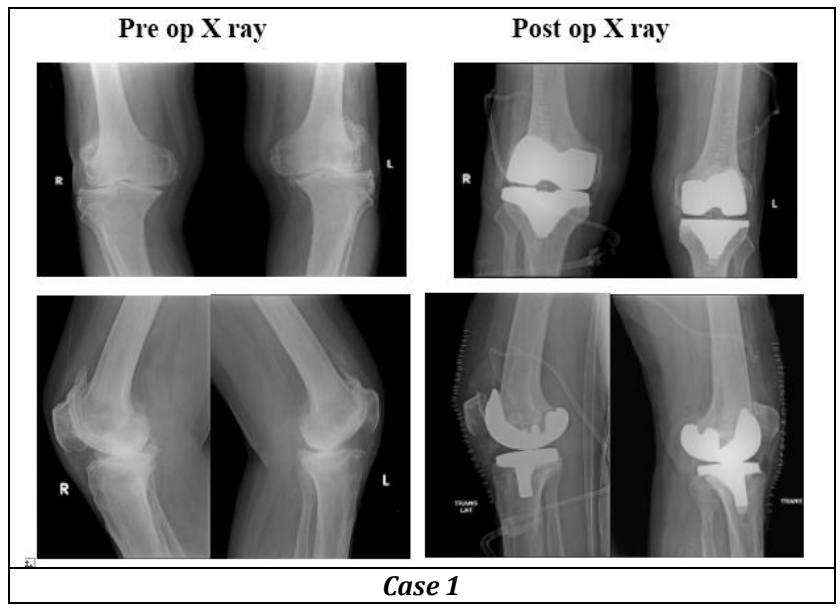



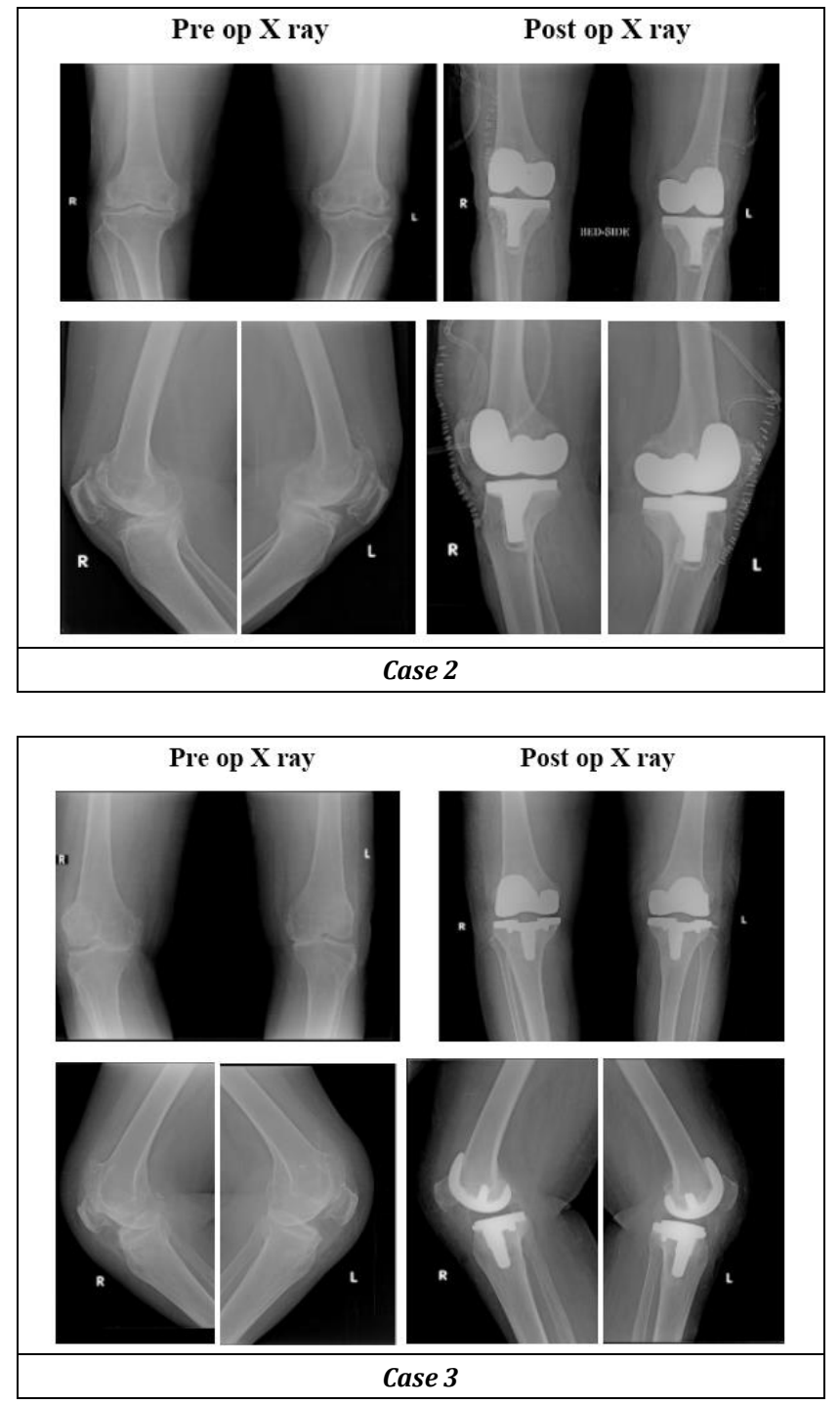

\begin{tabular}{|c|c|c|c|c|}
\hline & & $\begin{array}{c}\text { Pre- } \\
\text { operative } \\
\text { (47 Knees) }\end{array}$ & $\begin{array}{c}\text { Post- } \\
\text { operative } \\
\text { (47 Knees) }\end{array}$ & \\
\hline Pain & Nil & 0 & 25 & \\
\hline & $\begin{array}{c}\text { Mild or } \\
\text { occasional }\end{array}$ & 0 & 13 & \multirow{6}{*}{$\begin{array}{c}\operatorname{chi}^{2}=94.0 \\
\mathrm{df}=5 \\
\mathrm{p}=0.000 \\
\text { sig }\end{array}$} \\
\hline & Stairs only & 0 & 9 & \\
\hline & $\begin{array}{c}\text { Walking and } \\
\text { stairs }\end{array}$ & 0 & 0 & \\
\hline & $\begin{array}{c}\text { Moderate } \\
\text { occasional }\end{array}$ & 26 & 0 & \\
\hline & $\begin{array}{l}\text { Moderate } \\
\text { continual }\end{array}$ & 13 & 0 & \\
\hline & Severe & 8 & 0 & \\
\hline \multicolumn{5}{|c|}{ Range of motion (in degrees) } \\
\hline & $40-60$ & 13 & 0 & \multirow{4}{*}{$\begin{array}{c}\text { chi }^{2}=55.0 \\
\mathrm{df}=3 \\
\mathrm{p}=0.000 \\
\text { sig }\end{array}$} \\
\hline & $60-80$ & 12 & 3 & \\
\hline & $80-100$ & 19 & 6 & \\
\hline & $100-120$ & 3 & 38 & \\
\hline \multicolumn{5}{|c|}{ Anteroposterior stability } \\
\hline & $<5 \mathrm{~mm}$ & 34 & $\begin{array}{r}47 \\
\end{array}$ & \multirow{3}{*}{$\begin{array}{c}\operatorname{chi}^{2}=15.086 \\
\mathrm{df}=1 \\
\mathrm{p}=0.000 \\
\text { sig }\end{array}$} \\
\hline & $5-10 \mathrm{~mm}$ & 13 & 0 & \\
\hline & $10 \mathrm{~mm}$ & 0 & 0 & \\
\hline \multicolumn{5}{|c|}{ Mediolateral stability } \\
\hline & $<5$ & 17 & 43 & \multirow{4}{*}{$\begin{array}{c}\operatorname{chi}^{2}=31.83 \\
d f=2 \\
p=0.000, \text { sig }\end{array}$} \\
\hline & $6-9$ & 21 & 4 & \\
\hline & $10-14$ & 9 & 0 & \\
\hline & 15 & 0 & 0 & \\
\hline Deductions & & Preoperative & Postoperative & \\
\hline \multirow{2}{*}{\begin{tabular}{|c|}
$\begin{array}{c}\text { Flexion } \\
\text { contracture }\end{array}$ \\
\end{tabular}} & None & 8 & 43 & \multirow{2}{*}{$\begin{array}{c}\operatorname{chi}^{2}=53.937 \\
\mathrm{df}=3 \\
\mathrm{p}=0.000\end{array}$} \\
\hline & 5-10 degrees & 26 & 1 & \\
\hline
\end{tabular}

\begin{tabular}{|c|c|c|c|c|}
\hline & $\begin{array}{c}10-15 \\
\text { degrees }\end{array}$ & 10 & 3 & \multirow[t]{3}{*}{ sig } \\
\hline & $\begin{array}{c}16-20 \\
\text { degrees }\end{array}$ & 3 & 0 & \\
\hline & $>20$ degrees & 0 & 0 & \\
\hline \multirow[t]{3}{*}{$\begin{array}{c}\begin{array}{c}\text { Extension } \\
\text { lag }\end{array} \\
\end{array}$} & $<10$ degrees & 36 & 45 & \multirow{3}{*}{$\begin{array}{c}\text { chi }^{2}=7.33 \\
\mathrm{df}=2 \\
\mathrm{p}=0.003 \\
\text { sig }\end{array}$} \\
\hline & $\begin{array}{c}10-20 \\
\text { degrees }\end{array}$ & 10 & 2 & \\
\hline & $>20$ degrees & 1 & 0 & \\
\hline \multirow[t]{4}{*}{ Alignment } & 5-10 degrees & $\begin{array}{l}0 \text { (valgus) } \\
15 \text { (varus) }\end{array}$ & $\begin{array}{c}6 \text { (valgus) } \\
0 \text { (varus) }\end{array}$ & \\
\hline & 0-4 degrees & $\begin{array}{l}0 \text { (valgus) } \\
12 \text { (varus) }\end{array}$ & $\begin{array}{c}0 \text { (valgus) } \\
1 \text { (varus) }\end{array}$ & \\
\hline & $\begin{array}{c}11-15 \\
\text { degrees }\end{array}$ & $\begin{array}{l}2 \text { (valgus) } \\
10 \text { (varus) }\end{array}$ & 0 & \\
\hline & $>15$ & 8 (varus) & 0 & \\
\hline \multicolumn{5}{|c|}{ Table 1. Knee Society Scoring 1} \\
\hline
\end{tabular}

\begin{tabular}{|c|c|c|c|c|}
\hline & & $\begin{array}{c}\text { Pre- } \\
\text { Operative } \\
\text { (30 Patients) }\end{array}$ & \begin{tabular}{|c|} 
Post- \\
Operative \\
(30 Patients)
\end{tabular} & \\
\hline \multirow[t]{6}{*}{ Walking } & Unlimited & 0 & \begin{tabular}{|c|}
5 \\
\end{tabular} & \multirow{6}{*}{$\begin{array}{c}\operatorname{chi}^{2}=52.696 \\
\mathrm{df}=4 \\
\mathrm{p}=0.000 \\
\text { sig }\end{array}$} \\
\hline & $>10$ blocks & 0 & 23 & \\
\hline & 5-10 blocks & 21 & 2 & \\
\hline & $<5$ blocks & 7 & $\frac{2}{0}$ & \\
\hline & Housebound & 2 & 0 & \\
\hline & Unable & 0 & 0 & \\
\hline \multirow[t]{5}{*}{ Stairs } & $\begin{array}{c}\text { Normal up and } \\
\text { down }\end{array}$ & 0 & 3 & \multirow{5}{*}{$\begin{array}{c}\mathrm{chi}^{2}=47.545 \\
\mathrm{df}=4 \\
\mathrm{p}=0.000 \\
\text { sig }\end{array}$} \\
\hline & $\begin{array}{c}\text { Normal up, } \\
\text { down with rail }\end{array}$ & 0 & 21 & \\
\hline & $\begin{array}{c}\text { Up and down } \\
\text { with rail }\end{array}$ & 11 & 6 & \\
\hline & $\begin{array}{l}\text { Up with rail, } \\
\text { down unable }\end{array}$ & 17 & 0 & \\
\hline & Unable & 2 & 0 & \\
\hline \multirow[t]{4}{*}{ Walking aid } & None & 8 & 18 & \multirow{4}{*}{$\begin{array}{c}\mathrm{chi}^{2}=7.092 \\
\mathrm{df}=3 \\
\mathrm{p}=0.069 \\
\text { Not sig }\end{array}$} \\
\hline & Cane & 16 & 9 & \\
\hline & Two canes & 5 & 2 & \\
\hline & $\begin{array}{c}\text { Crutches or } \\
\text { walker }\end{array}$ & 1 & 1 & \\
\hline \multicolumn{5}{|c|}{ Table 2. Functional Scoring } \\
\hline
\end{tabular}

\begin{tabular}{|c|c|c|}
\hline Knee Score (47 Knees) & Pre-Operative & Post-Operative \\
\hline $80-100$ Excellent & 0 & 43 \\
\hline $70-79$ Good & 0 & 4 \\
\hline $60-69$ Fair & 0 & 0 \\
\hline$<60$ Poor & 47 & 0 \\
\hline \multicolumn{2}{|c|}{ Table 3. Results-Knee Score } \\
\hline \multicolumn{2}{|c|}{ Chi $^{2}=94.0, \mathrm{df}=2, \mathrm{p}=0.000$,sig } \\
\hline
\end{tabular}

\begin{tabular}{|c|c|c|}
\hline $\begin{array}{c}\text { Functional Score (30 } \\
\text { Patients) }\end{array}$ & Pre-Operative & Post-Operative \\
\hline 80-100 Excellent & 0 & 20 \\
\hline 70-79 Good & 0 & 8 \\
\hline $60-69$ Fair & 0 & 1 \\
\hline$<60$ Poor & 30 & 1 \\
\hline \multicolumn{2}{|c|}{ Table 4. Results-Functional Score } \\
\hline \multicolumn{2}{|c|}{ Chi2 $=49.091, \mathrm{df}=3, \mathrm{p}=0.000$, sig } \\
\hline
\end{tabular}

\begin{tabular}{|c|c|c|c|c|c|}
\hline Indications & $\begin{array}{c}\text { No. of } \\
\text { Knees }\end{array}$ & $\begin{array}{c}\text { Pre- } \\
\text { Operative }\end{array}$ & $\begin{array}{c}\text { Post- } \\
\text { Operative }\end{array}$ & t-Value & p Value \\
\hline OA & 41 & $\begin{array}{c}\text { Mean- 32.4 } \\
\text { Standard } \\
\text { deviation- } \\
7.78\end{array}$ & $\begin{array}{c}\text { Mean- } 87.4 \\
\text { Standard } \\
\text { deviation- } \\
5.97\end{array}$ & 33.8 & 0.000 sig \\
\hline RA & 6 & $\begin{array}{c}\text { Mean- } 39.3 \\
\text { Standard } \\
\text { deviation- } \\
4.19\end{array}$ & $\begin{array}{c}\text { Mean-90 } \\
\text { Standard } \\
\text { deviation-5.39 }\end{array}$ & 12.7 & 0.000 sig \\
\hline
\end{tabular}

Table 5. Comparison of Knee Score Outcomes in Different Indications

Post-op p value in comparison with both groups was 0.252 , which is insignificant. 


\begin{tabular}{|c|c|c|c|c|c|}
\hline Indications & $\begin{array}{l}\text { No. of } \\
\text { Knees }\end{array}$ & $\begin{array}{c}\text { Pre- } \\
\text { Operative }\end{array}$ & $\begin{array}{c}\text { Post- } \\
\text { Operative }\end{array}$ & t-value & p Value \\
\hline $\mathrm{OA}$ & 41 & $\begin{array}{c}\text { Mean - } 35.2 \\
\text { Standard } \\
\text { deviation- } \\
8.72 \\
\end{array}$ & $\begin{array}{c}\text { Mean - 78.9 } \\
\text { Standard } \\
\text { deviation- } \\
3.81 \\
\end{array}$ & 19.7 & $0.000 \mathrm{sig}$ \\
\hline RA & 6 & $\begin{array}{c}\text { Mean - 42.5 } \\
\text { Standard } \\
\text { deviation- } \\
11.08\end{array}$ & $\begin{array}{c}\text { Mean - 74.17 } \\
\text { Standard } \\
\text { deviation- } \\
12.39\end{array}$ & 6.6 & 0.000 sig \\
\hline \multicolumn{6}{|c|}{$\begin{array}{l}\text { Table 6. Comparison of Functional Score Outcomes in Different } \\
\text { Indications }\end{array}$} \\
\hline \multicolumn{6}{|c|}{$\begin{array}{l}\text { Post-op p value in comparison with both groups was } 0.441 \text {, which is } \\
\text { insignificant. }\end{array}$} \\
\hline
\end{tabular}

\begin{tabular}{|c|c|c|c|c|c|c|c|}
\hline Study & Year & Subjects & \% Male & $\begin{array}{c}\text { Mean } \\
\text { Age }\end{array}$ & ROM & $\begin{array}{c}\text { KSS } \\
\text { Pain }\end{array}$ & KSS \\
\hline Aligetti & 2005 & 103 & 14 & 71.0 & NO & NO & 93 \\
\hline Watanabe & 2005 & 22 & 4.5 & 59.6 & - & 49.7 & 91.8 \\
\hline Harrington & 2009 & 68 & 41.2 & 63.7 & 117.7 & NR & 91.4 \\
\hline Kim & 2009 & 92 & 7.6 & 69.5 & 127 & 44 & 94 \\
\hline Our Study & & 30 & 20 & 61.6 & 110 & 46.7 & 87.7 \\
\hline
\end{tabular}

Table 7. Post Op Knee Score Illustrated in Other Studies ${ }^{2}$

In our study Pre-operative mean knee society score for pain was 13.8 and postoperative score was 46.7 .

In our study average pre-operative range of movement was 0 to 90 degrees of flexion and average post-operative range of movement was 0 to 110 degrees of flexion.

In our study, preoperative score for stairs was 19.5 and post-operative score was 39.0. Postoperatively three patients had normal up and down of stairs, 21 patients had normal up and down with rails and 6 patients had up and down with rails. In our study, all the 47 knees had poor knee score of $<60$ preoperatively, postoperatively 28 knees had excellent score (80-100) and 19 knees with good score (70-79), with p value of 0.000 , showing significant improvement in the knee score following Total knee replacement. Knee score: Preoperative-33.27 Post-operative-87.7

In our study, all patients had poor functional score $(<60)$ pre-operatively, postoperatively 20 patients had excellent score (80-100), 8 patients with good score (70-79), 1 patient had fair score $(60-69)$ and 1 patient had poor score $(<60)$.

Preoperative mean score of 36.67 increased to 78 postoperatively with $\mathrm{p}$ value of 0.000 , indicating significant improvement in functional score following Total knee replacement. Functional score: Pre-operative-36.67 Postoperative-78.

\section{DISCUSSION}

In our study of "Functional Outcome of Total Knee Arthroplasty" we evaluated 30 patients (47 Knees) who underwent total knee replacement at SVS medical college hospital during the year October 2012 - September 2014.

We had $24(80 \%)$ female patients and $6(20 \%)$ male patients, Age of the patients in our study was 6 cases from age group 51-55 yrs., 8 cases from 56-60 yrs., 7 cases from 61-65 yrs., 7 patients were $66-70$ and 3 patients were above 70 yrs., accounting for mean age of 61.6 years. In our study Pre-operative knee society score for pain was 13.8 and postoperative score was 46.7, Average Range of movement in our study pre-operatively was 0 to 90 degrees of flexion and average post-operative range of movement was 0 to 110 degrees of flexion. These results are comparable with the studies done by Aligetti et al., Watanabe et al., Harrington et al., Kim et al. ${ }^{5}$
Most of the indications in our study belongs to Osteoarthritis (41 Knees) and rheumatoid Arthritis (6 Knees). Pascal A. Schai et al. reported that there were 145 knees with osteoarthritis and 77 with rheumatoid arthritis, five with post-traumatic arthritis. ${ }^{6}$ M. Salman Ali reported osteoarthritis in 94 knees, rheumatoid arthritis in 14 knees, and posttraumatic osteoarthritis in 1 knee. $^{7}$

17 patients $(56.6 \%)$ underwent bilateral Total Knee Replacement, 7 patients to right knees (23.3\%) and 6 (20\%) patients to left knees. In other studies, William. F Donaldson III reports $48.1 \%$ right $28 \%$ left and $24 \%$ bilateral. $^{8}$

13 knees had A-P instability of 5 - $10 \mathrm{~mm}$ preoperatively, post operatively all the 47 knees showed no A-P instability. 9 knees had M-L instability of $10-14 \mathrm{~mm}, 21$ knees with M-L instability of 6-9 $\mathrm{mm}$ and 17 knees without M-L instability preoperatively, post-operatively 4 knees had M-L instability of 6-9 mm and 43 knees had no M-L instability, with p value of 0.000 , which is significant.

We had 3 knees with FFD of 16-20 degree, 10 knees with FFD of 11- 15 degree, 26 knees with FFD of 5-10 degree preoperatively. Post-operatively 43 knees did not have FFD, 3 knees had FFD of 11-15 degree and 1 knee had FFD of 5-10 degree, with a significant $p$ value of 0.000 . Results of other studies, Wine Maker M. et al. has observed $72 \%$ of patients with FFD had difficulty in kneeling post op and 38\% had difficulty in stair climbing as compared to $44 \%$ and $26 \%$ respectively for non-stiff knees. ${ }^{9}$

William J Maloney et al has noted in both the TC \& PSTC designs there was statistically significant improvement in flexion contracture from $12^{\circ}-2^{\circ}$ in TC, $10^{\circ}-4^{\circ}$ in PSTC. He observed no difference in flexion contracture correction between TC \& PSTC groups. ${ }^{10}$ One knee had extension lag of > 20 degree, 10 knees had extension lag of 10-20 degrees and 36 knees with extension lag of $<10$ degree preoperatively. Post- operatively 45 knees had extension lag of $<10$ degrees and 2 knees with extension lag of 15 degree, with a significant $\mathrm{p}$ value of 0.003 . Preoperatively we had 3 knees with $>20$ degree of varus, 5 knees with 16-20 degree of varus, 10 knees with varus of 11-15 degree, 15 knees with 5-10 degree of varus, 12 knees with 0-4 degree of varus, 2 knees with 11-15 degree of valgus. Postoperatively we had 46 knees with normal valgus of 5-10 degree and 1 knee with residual varus of 0-4 degree. Young Hoo Kim et al. reported in 103 knees with $84 \%$ patients having varus of 8.5 degrees and $16 \%$ with 5.7 degrees valgus pre operatively and post operatively all the patients were retained with normal physiological valgus of 5 - 10 degrees. ${ }^{11}$ William. F. Donaldson III et al. reports that all 25 knees $(100 \%)$ were in $0-10^{\circ}$ after operation. However, in long-term follow-up evaluations of 25 knees, the alignment was neutral to $10^{\circ}$ valgus in 23 knees (92\%). One knee had less than $5^{\circ}$

varus, one knee was in greater than $10^{\circ}$ varus alignment. ${ }^{8}$

We had 2 patients who were housebound, 7 patients who could walk $<5$ blocks and 21 patients with walking ability of 5 - 10 blocks preoperatively. Post operatively 5 patients could walk unlimited distance, 23 patients $>10$ blocks and 2 patients 5- 10 blocks, with significant $p$ value of 0.000 .

Pre operatively no patients were able to walk stairs up and down normally, 17 patients up with rail and unable to walk down, 11 patients were able to walk stairs up and down with rail and 2 patients were unable to walk up and down stairs. 
Postoperatively 3 patients had normal up and down of stairs, 21 patients had normal up and down with rails and 6 patients had up and down with rails. $p$ value is 0.000 , which is significant.

Preoperatively 16 patients were using a cane and 1 patient was using walker, 5 patients were using two canes. Postoperatively 9 patients were using a cane and 1 patient was using walker, 2 patients with two canes and 18 patients without any support, with an in-significant $p$ value of 0.069 .

In our study Average KSS pre operatively was 33.34 and post-operative average KSS was 87.7. These results are comparable with the studies done by Aligetti et al., Watanabe et al., Harrington et al., Kim et al. ${ }^{5}$

In our study, 30 patients had poor functional score preoperatively. Postoperatively 20 patients had excellent score (80-100), 8 patients with good score (70-79), 1 patient had fair score (60-69) and 1 patient poor score $(<60)$. Preoperative mean score of 40.8 increased to 77.2 postoperatively with $\mathrm{p}$ value of 0.000 , indicating significant improvement in functional score following Total knee replacement. The fair and poor functional score was because of irregular follow up of the patient to the OPD and noncompliance with the physiotherapy.

In our study postoperative knee score in Osteoarthritis knees were 90.3, in Rheumatoid Arthritis knees were 87.3. We compared the results of the 2 groups, the $p$ value is 0.252 which is not significant.

In our study postoperative functional score in Osteoarthritis knees were 78.4, in Rheumatoid Arthritis knees were 75.8, we compared the results of the two groups, the $\mathrm{p}$ value was 0.441 , which is not significant.

In our study we didn't encounter with any of the complications associated with TKR.

\section{CONCLUSIONS}

TKR is a common and well-accepted intervention for advanced knee arthritis and, thus, maximizing functional outcomes is of utmost priority. Total Knee Replacement has evolved as a very effective surgical intervention after the conservative methods like NSAID's, Physiotherapy, Intraarticular steroid and Hyaluronic acid injections have failed. TKR is associated with numerous complications intra and post operatively and the surgeon should be aware of the complications and need for the revision in a later stage. Preop evaluation of the patient is of utmost importance in planning the amount of correction to be achieved, component sizing, and requirement of wedge or bone grafts for bone loss. TKR even in young patients offers excellent results with early return to their daily activities. With the invention of newer equipment and instruments TKR has been made easy and more accurate for the surgeon to retain normal kinematics of the knee. Our study of "Functional Outcome of Total Knee Arthroplasty" series demonstrates that primary total knee replacement is a reliable procedure which provides pain relief, improves range of motion, gives good function and corrects the deformities and it can be performed successfully, with minimal complications, at a district level hospital.

\section{REFERENCES}

[1] Drake RL, Vogl W, Mitchell AWM. Gray's Anatomy for students. $3^{\text {rd }}$ edn. Philadelphia: Churchill Livingstone/ Elsevier 2015.

[2] Kane RL, Saleh KJ, Wilt TJ, et al. The functional outcomes of total Knee arthroplasty. The Journal of Bone \& Joint Surgery Am 2005;87(8):1719-24.

[3] Hinman RS, Bennell K, Metcalf B, et al. Delayed onset of quadriceps activity and altered knee joint kinematics during stair stepping in individuals with knee osteoarthritis. Arch Phys Med Rehabil 2002;83(8):1080-6.

[4] Insall JN, Dorr LD, Scott RD, et al. Rationale of the knee society clinical rating system. Clin Orthop Relat Res 1989;248:13-4.

[5] Smith H, Jan M, Mahomed NN, et al. Meta-analysis and systemic review of clinical outcomes comparing mobile bearing and Fixed bearing Total Knee arthroplasty. Journal of Arthroplasty 2011;26(8):1205-13.

[6] Schail PA, Thornill TS, Scott RD. Total Knee arthroplasty with PFC system. Results at a minimum of ten years and survivorship analysis. J Bone Joint Surg Br 1998;80(5):850-8.

[7] Ali SM, Mangaleshkar SR. Uncemented rotatingplatform total Knee arthroplasty: a 4-year to 12-year follow-up. Journal of Arthroplasty 2006;21(1):80-4.

[8] Donaldson 3rd WF, Sculco TP, Insall JN, et al. Total condylar knee III prosthesis long-term follow-up study. Clinical Orthopaedics and Related Research 1988;(226):21-8.

[9] Winemaker M, Rahman WA, Petruccelli D, et al. Preoperative Knee stiffness and total knee arthroplasty outcomes. The Journal of Arthroplasty 2012;27(8):1437-41.

[10] Maloney WJ, Schurman DJ. The effects of implant design on range of motion after total knee arthroplasty. Total condylar versus posterior stabilized total condylar designs. Clin Orthop Relat Res 1992;(278):147-52.

[11] Kim YH, Kim JS. Does TKR improve functional outcome and range of motion in patients with stiff Knee? Clinical Orthopaedics and Related Research 2009;467(5):1348-54. 